\title{
Effects of cervical myofascial trigger points release in post-natal females: A randomized controlled trial
}

\section{Efectos de la liberación de puntos gatillo miofasciales cervicales en mujeres después del parto: Un ensayo controlado aleatorizado}

\author{
Marwa Esmael Hasanin ${ }^{1}$, Rania Reda Mohamed ${ }^{2}$, Hamada Ahmed Hamada ${ }^{3 *}$, Abeer Farag \\ Hanafy $^{4}$ \\ ${ }^{1}$ Department of Physical Therapy for Woman's Health, Faculty of Physical Therapy, Cairo \\ University, Egypt \\ ${ }^{2}$ Department of Basic Science, Faculty of Physical Therapy, Cairo University, Egypt \\ ${ }^{34}$ Department of Biomechanics, Faculty of Physical Therapy, Cairo University, Egypt \\ * Hamada Ahmed Hamada; hamada.ahmed@pt.cu.edu.eg
}

\begin{abstract}
The aim was to investigate and compare the effectiveness of Ultrasound (US) versus a combination of US and ischemic compression (IC) technique on headache pain intensity and range of motion (ROM) of the cervical region in healthy females with myofascial trigger points (MTrPs) in the cervical muscles, following normal delivery. Forty females (ages 20-35 years) with MTrPs in the muscles of the neck took part in the study. They were assigned into control group (US therapy for the MTrPs of the upper trapezius and sub-occipital muscles) and study group (IC technique on the active MTrPs of the muscles in addition to the US application). They received eight sessions for 4 weeks (2 sessions/week). All patients were evaluated before and after treatment for the intensity of radiating headache by Visual Analogue Scale (VAS) and the universal goniometer to measure cervical ROM. Two-way mixed design MANOVA demonstrated a significant decrease $(p<0.05)$ in headache pain intensity and a significant increase $(\mathrm{p}<0.05)$ in neck flexion, extension, right and left side bending, and rotation in both groups when compared to pre-treatment circumstances. Additionally, there was a significant reduction in pain intensity after treatment in the study group compared to the control group $(p<0.05)$. In conclusion, in healthy females after normal delivery, US alone or in combination with the IC technique is effective for releasing cervical myofascial trigger points and has positive effects on radiating headache and cervical ROM. In addition, IC technique was a complement to US in reducing
\end{abstract}


the severity of headache pain, but its effect on improving cervical ROM was practically but not statistically significant.

\section{KEYWORDS}

Trigger points; Goniometer; Ischemic compression; Ultrasound.

\section{RESUMEN}

El objetivo fue investigar y comparar la eficacia del ultrasonido (US) frente a una combinación de US y compresión isquémica (CI) sobre la intensidad del dolor de cabeza y el rango de movimiento (ROM) de la región cervical en mujeres sanas con puntos gatillo miofasciales (PGM) en los músculos cervicales, después de un parto normal. Participaron en el estudio cuarenta mujeres (de 20 a 35 años) con PGM en los músculos del cuello. Fueron asignadas al grupo control (terapia de US Para los PGM del trapecio superior y los músculos suboccipitales) y al grupo de estudio (técnica de CI sobre los PGM activos de los músculos, además de la aplicación de US). Recibieron ocho sesiones durante 4 semanas ( 2 sesiones/semana). Todos los pacientes fueron evaluados antes y después del tratamiento para determinar la intensidad del dolor de cabeza irradiado, mediante la Escala Visual Analógica (EVA) y el goniómetro universal para medir el ROM cervical. MANOVA de diseño mixto bidireccional demostró una disminución significativa $(\mathrm{p}<0,05)$ en la intensidad del dolor de cabeza y un aumento significativo $(\mathrm{p}<0,05)$ en la flexión, extensión, flexión del lado derecho e izquierdo y rotación del cuello en ambos grupos en comparación con la evaluación pre-tratamiento. Además, hubo una reducción significativa en la intensidad del dolor después del tratamiento en el grupo de estudio en comparación con el grupo de control $(\mathrm{p}<0,05)$. En conclusión, en mujeres sanas después de un parto normal, el US solo o en combinación con la técnica de CI es eficaz para liberar los puntos gatillo miofasciales cervicales y tiene efectos positivos sobre el dolor de cabeza irradiado y el ROM cervical. Además, la técnica de CI fue un complemento del US para reducir la gravedad del dolor de cabeza, aunque su efecto sobre la mejora del ROM cervical fue clínicamente significativo pero no estadísticamente significativo.

\section{PALABRAS CLAVE}

Puntos gatillo; Goniómetro; Compresión isquémica; Ultrasonido. 


\section{INTRODUCTION}

Myofacial trigger points (MTrPs) in the skeletal muscle are described as palpable tender nodules inside a taut muscular band that result in a local twitch response and referred pain when activated (Couppe et al.,2007; Fernandez-De-las-Penas et al., 2007). They are considered major causes of pain in $85 \%$ of individuals who visit pain clinics. The most common affected locations are the head/neck, elbows, extremities, and low back, with women having a higher frequency than men (Majlesi \& Unalan, 2010).

Headache and neck or shoulder pain, particularly in those between 25 and 35 years old, are one of the most common symptoms in about $39 \%$ of females in the first 6 weeks after delivery (Goldszmidt, Kern, Chaput \& Macarthur, 2005; Macarthur, 2009). These symptoms are caused by biomechanical changes in body posture that occur during pregnancy as a result of the anatomic and physiological changes that occur during this period of life. Almost all women seem to suffer from musculoskeletal discomforts during pregnancy, which can last for months after delivery due to hormonal effects and the ergonomic stress of caring and feeding the newborn (Borg-Stein \& Dugan, 2007).

MTrPs in the cervical muscles can be activated by postural and musculoskeletal discomforts and abnormalities, including the cervical spine. Referred pain may extend from the occipital and temporal bones to the sides of the head. Bilateral headaches can arise from this referred pain spreading to both sides (Gerwin, 2005).

Pain medications may be troublesome as a form of pain management, either because of their accumulation in breast milk or because of their effect on newborn. As a result, treating muscle tension and headaches with manual therapy and/or non-pharmacological modalities can relieve pain and stress, while having few side effects, making it an appealing choice for pregnant and breastfeeding women (Marcus \& Bain, 2009).

Ischemic compression (IC) is the method of gradually adding pressure to a trigger point in order to eliminate it. The treatment entails compressing the trigger points with tolerable pain intensity using thumb pressure, then gradually increasing the compression intensity as the degree of discomfort reduces (Simons \& Dommerholt, 2005). The aim of IC is to minimize MTrPs and improve the range of cervical motion (ROM) in neck pain patients. It was also speculated that inhibiting the MTrPs in the cervical musculature decreases headache pain (Fernandez-de-las-Penas et al., 2010). 


\section{LITERATURE REVIEW}

Cervical spine disorders are the most common health issues and the leading cause of disability (Rahmani et al., 2013). These conditions are usually causing changes in the ROM of the cervical spine (Williams, Williamson, Gates \& Cooke, 2012). When patients with neck pain attend physical therapy clinics, their cervical ROM is regularly assessed (De Koning, 2008). It can assist the physiotherapist in assessing the condition, formulating the prognosis, developing a treatment plan, tracking progress, and evaluating treatment efficacy (Agarwal, Allison, Singer, 2005).

The cervical range of motion can be measured using various measurement devices. They vary in complexity from simple instruments like the Universal Goniometer (UG), which is commonly used in the field of physical therapy, to highly complex devices. Universal Goniometer (UG) emerges as a lowcost, simple alternative for global use (Yankai, Manosan, 2009).

According to a study done by Farooq et al. (2016), the UG measurements for evaluating active cervical ROM have excellent inter and intra-rater reliability. The results demonstrated that the UG is a trustworthy tool for determining cervical range of motion. The UG is a low-cost, easy-to-use tool that requires minimum training (Farooq, Mohseni-Bandpei, Ali \& Khan, 2016).

In healthy females after normal delivery, no research has yet compared the effect of ultrasound alone or in combination with ischemic compression (IC) technique on the severity of radiating headache and cervical ROM. As a result, this study was done to determine the effect of using ultrasound alone or accompanied with IC technique on the radiating headache pain and cervical range of motion in myofacial trigger points of post-natal females.

\section{METHODS}

\subsection{Study Design}

This study was prospective, randomized, single-blind, pre-post-test, and controlled experiment. The ethical approval was given by the institutional Review Board of Cairo University's Faculty of Physical Therapy before starting the study. This report adheres to the Declaration of Helsinki Guidelines for the Conduct of Human Research. The research was carried out between October 2019 to January 2020. 


\subsection{Participants}

This research included forty female patients with myofacial trigger point pain in the neck muscles (trapezius and suboccipital muscles), and with ages ranging from 20 to 35 years old (Table 1). Patients were eligible for the study if it was their first time having a normal vaginal delivery (up to 6 months after delivery) and they planned to breastfeed normally. The patients that were included in the study should have a hypersensitive tender spot, a palpable taut band and a local twitch response, elicited by the snapping palpation of the taut band and in response to compression, a spontaneous appearance of the typical referred pain pattern of the MTrPs and headache. Patients were ruled out if they had hypertension or hypotension, chronic sinusitis, cancers, intracranial disorder, a history of musculoskeletal disorders, or if they had been given regional or epidural anaesthesia throughout delivery. All patients were recruited from the Post-Natal Clinics of Cairo University and Medical Educational Institutes, Cairo, Egypt.

\subsection{Randomization}

Each participant signed an informed written permission form after learning about the study's nature, aim, and benefits, as well as their right to decline or withdraw at any time and the confidentiality of any information acquired. All data was digitized to protect anonymity. The patients were assigned into control or study groups by computer-generated random numbers. To hide the distribution, numbered envelopes were used.

\subsection{Instruments}

The headache pain intensity was assessed by using VAS as it is a valid and trustworthy tool for pain assessment (Carlsson, 1983). The Standard Universal Goniometer was used to determine the neck ROM from a sitting position to remove inaccuracies and movement compensation. For all patients, a $2 \mathrm{w} / \mathrm{cm} 2,1-\mathrm{MHz}$ ultrasound was delivered to the active MTrPs of the neck muscle. In addition, the Ischemic Compression (IC) technique was performed on the upper trapezius and suboccipital active MTrPs for patients in the study group only (group II). 


\subsection{Procedure}

\subsubsection{Initial Assessment}

The VAS was used for assessing the headache pain intensity. Each patient was asked to mark the grade representing her maximum pain intensity in every attack of the headache (Bijur, Wendy $\&$ Gallagher, 2001). The scores were taken before the starting of the treatment and were repeated after 4 weeks (at the end of the treatment program). Then each patient was asked to sit with her back straight on a chair with support at the lumbar curve without any restrictive clothes. To minimize thoracic movement, the patient's ankles, knees, and hips were placed at a right angle and her arms were folded across her chest. From the sitting position, the standard universal goniometer was used to assess the cervical ROM. The patient was advised to raise her head as far as she could in the following directions: flexion, extension, side bending (right and left), and rotation (right and left side). Each movement was performed three times. After that, the movements were scored and averaged (Yankai \& Manosan, 2009).

\subsubsection{Intervention}

- Group I (Control Group): included 20 patients who received US therapy, with $2 \mathrm{w} / \mathrm{cm}^{2}$ intensity and a frequency of (1-MHz). On the upper trapezius and suboccipital active MTrPs, a continuous mode with a duration of 5 minutes was used (Kavadar et al., 2015).

- Group II (Study Group): included 20 patients who received US treatment with the same criteria as group (I) plus IC technique on the active MTrPs of the same muscles. The IC consisted of continuous, perpendicular deep thumb fingertip pressure to the identified suboccipital and upper trapezius muscles trigger points continuously for 90 seconds (Kumar, Sneha \& Sivajyothi, 2015). The therapist started with light firm pressure and gradually increased it until the patient said the pain was "moderate but bearable." The pressure was held at this stage until the pain subsided. The same protocol was followed for each of the remaining points (one by one) (Ferreira \& Herbert, 2008).

- The program of treatment that was delivered to all patients in both groups (I \& II) had a duration of 4 weeks ( 2 sessions/week). The same whole initial assessment procedure was repeated again after the 4 weeks of treatment for all patients in both groups. 


\subsection{Statistical analysis}

The Statistical Package for Social Science (SPSS) software version 23 for Windows was used for all statistical analyses. The data were examined for normality assumptions and the existence of extreme scores before final analysis. This study was carried out as a pre-requisite to the parametric measurement of the analysis of difference and related measures. According to descriptive analysis utilizing histograms with the normal distribution curve, the data for neck flexion, extension, right and left side bending, and rotation were normally distributed and did not contradict the parametric assumption. The homogeneity of covariance was further tested using the Box's test, which found no significant differences with $\mathrm{p}$ values of $>0.05$. The Shapiro-Wilk test was used to examine if the data for neck flexion, extension, right and left side bending, and rotation was regularly distributed. The researchers were able to conduct parametric analysis as a result of their findings. To compare the tested variables of interest at different tested groups and measurement times, a 2x2 mixed design MANOVA was performed. For this analysis, the alpha level was set at 0.05 .

Table 1. Demographic characteristics of patients in both groups

\begin{tabular}{ccccc}
\hline & Control group & Study group & T-test & P-values* \\
\hline Age (years) & $29.60 \pm 3.57$ & $29.40 \pm 3.42$ & 0.181 & 0.85 \\
\hline
\end{tabular}

\section{RESULTS}

A total of 40 patients met the inclusion criteria and were assigned randomly to study research interventions. Twenty patients in the control group received only US while twenty patients in the study group received both US and IC techniques. All the randomized patients took part in the investigation. The independent $\mathrm{t}$-test showed no significant difference in age between subjects in both groups (P > 0.05), as it is shown in Table 1.

The use of a mixed design for statistical analysis MANOVA revealed that there was a significant within-subject effect $(\mathrm{F}=127.911, \mathrm{p}=0.0001)$ as well as a significant treatment*time effect $(\mathrm{F}=2.526$, $\mathrm{p}=0.049^{*}$ ). Tables 2 and 3 show descriptive statistics for all dependent variables within and between groups for the impact of interventions. In a similar vein, the multiple pairwise comparison tests revealed a significant decrease in pain $(\mathrm{p}<0.05)$ and a significant increase $(\mathrm{p}<0.05)$ in neck flexion, extension, right and left side bending, and rotation in the post treatment condition compared to the pre- 
treatment condition in both groups. In terms of between-subject effects, multiple pairwise comparisons revealed a significant difference in pain between the two groups after treatment $(p<0.05)$, with the study group benefiting from this significant reduction in pain, although there were no significant differences $(p>0.05)$ in neck flexion, extension, right and left side bending and rotation between both groups.

Table 2. Descriptive statistics for all the dependent variables for both groups at different training periods

\begin{tabular}{rrrrr}
\hline & \multicolumn{2}{c}{ Control group } & \multicolumn{2}{c}{ Study group } \\
\hline Variables & \multicolumn{1}{c}{ Pre } & \multicolumn{1}{c}{ Post } & Pre & \multicolumn{1}{c}{ Post } \\
Pain Severity & $7.95 \pm 1.41$ & $4.21 \pm 2.03$ & $8.45 \pm 1.48$ & $2.61 \pm 1.01$ \\
Flexion & $37.5 \pm 5.01$ & $42.57 \pm 5.28$ & $39.14 \pm 5.65$ & $45.64 \pm 4.86$ \\
Extension & $47.35 \pm 3.38$ & $53.07 \pm 3.31$ & $46.78 \pm 3.72$ & $53.78 \pm 3.88$ \\
Right side bending & $36.5 \pm 4.07$ & $41 \pm 3.76$ & $35.92 \pm 4.35$ & $42.21 \pm 3.09$ \\
Left side bending & $36.42 \pm 3.95$ & $41.42 \pm 4.89$ & $36 \pm 4.35$ & $42.14 \pm 3.77$ \\
Right rotation & $65.35 \pm 5.04$ & $71.85 \pm 4.22$ & $66.07 \pm 5.66$ & $73.07 \pm 4.06$ \\
Left rotation & $65.78 \pm 4.82$ & $72.14 \pm 4.95$ & $66 \pm 5.18$ & $73.64 \pm 4.18$ \\
\hline
\end{tabular}

Values of all dependent variables are expressed as mean $\pm S D$.

Table 3. Multiple pairwise comparison tests (post hoc tests) for all the dependent variables in both groups

\begin{tabular}{|c|c|c|c|c|c|c|c|}
\hline \multicolumn{8}{|c|}{ Within groups (pre vs. post) } \\
\hline p-value & $\begin{array}{r}\text { Pain } \\
\text { Severity }\end{array}$ & Flexion & Extension & $\begin{array}{c}\text { Right side } \\
\text { bending }\end{array}$ & $\begin{array}{l}\text { Left side } \\
\text { bending }\end{array}$ & $\begin{array}{l}\text { Right } \\
\text { rotation }\end{array}$ & $\begin{array}{c}\text { Left } \\
\text { rotation }\end{array}$ \\
\hline $\begin{array}{l}\text { Study } \\
\text { group }\end{array}$ & $0.0001^{*}$ & $0.0001 *$ & $0.0001^{*}$ & $0.0001^{*}$ & $0.0001 *$ & $0.0001^{*}$ & 0.0001 \\
\hline $\begin{array}{c}\text { Control } \\
\text { group }\end{array}$ & $0.0001^{*}$ & $0.0001 *$ & $0.0001 *$ & $0.0001 *$ & $0.0001 *$ & $0.0001 *$ & $0.0001 *$ \\
\hline \multicolumn{8}{|c|}{ Between groups (study vs. control) } \\
\hline p-value & $\begin{array}{r}\text { Pain } \\
\text { Severity }\end{array}$ & Flexion & Extension & $\begin{array}{c}\text { Right side } \\
\text { bending }\end{array}$ & $\begin{array}{l}\text { Left side } \\
\text { bending }\end{array}$ & $\begin{array}{l}\text { Right } \\
\text { rotation }\end{array}$ & $\begin{array}{c}\text { Left } \\
\text { rotation }\end{array}$ \\
\hline $\begin{array}{r}\text { Pre- } \\
\text { treatment }\end{array}$ & 0.37 & 0.424 & 0.675 & 0.723 & 0.787 & 0.727 & 0.911 \\
\hline $\begin{array}{r}\text { Post } \\
\text { treatment }\end{array}$ & $0.014 *$ & 0.122 & 0.605 & 0.359 & 0.669 & 0.445 & 0.395 \\
\hline
\end{tabular}

*Significant at the alpha level $(p<0.05)$ 


\section{DISCUSSION}

MTrPs occur due to repetitive muscle overload or overuse, asymmetries, or biomechanical differences. Many of these are things that women go through during their pregnancies. Because of the added baby weight and growing uterus, the females posture changes during pregnancy. As a result, the muscles will need to adapt significantly, resulting in increased tension and overuse of the skeletal muscles (Dusunceli, Ozturk, Atamaz \& Durmaz, 2009). Acute or chronic muscle overload develop MTrPs, which damages the muscle motor endplate and triggers acetylcholine release. Excess acetylcholine generates contraction knots which result in local ischemia and hypoxia (Simons, 2004).

The findings of this study showed that there was a significant decrease in headache pain severity $(p<0.05)$ and a significant increase $(p<0.05)$ in neck flexion, extension, right and left side bending, and rotation in the post-treatment condition compared to the pre-treatment condition in both groups. After treatment, multiple pairwise comparisons demonstrated a significant difference in pain between the two groups $(p<0.05)$, with the study group benefiting from the significant pain reduction. While there were no significant differences $(\mathrm{p}>0.05)$ in neck flexion, extension, right and left side bending, and rotation between the two groups, there were significant differences in neck flexion, extension, right and left side bending, and rotation within groups.

Ultrasound is one of the most commonly utilized methods for the treatment of MTrPs. Its thermogenic impact increases the flexibility of thick collagenous tissues including tendons, ligaments, and joint capsules for a short period of time, reducing joint stiffness, discomfort, and muscle spasm while simultaneously improving blood flow (Robertson \& Baker, 2001). The effectiveness of US treatment in managing myofascial pain syndrome may be explained by increased blood flow (depending on the amount of pain-causing mediators extracted from the environment), nerve conduction changes, or changes in cell membrane permeability (depending on the reduction in inflammation), increased capillary density in muscle tissue and increased cellular energy intake, as well as by faster tissue healing and improved persistent muscle spasms (Watson, 2000).

Therapeutic ultrasound has an effect on pain central mechanisms. The number of dorsal horn neuronal Nitric Oxide Synthase-like neurons changes as a result of US therapy. It works by affecting the regulation of central neural circuits, which reduces pain (Hsieh, 2005). The effect of US in releasing the triggering point and subsequent decrease in radiating headache pain in both groups in the current study agreed with the results of Srbely et al. (2008). Low doses of US therapy raised the pain pressure threshold and decreased the sensitivity of the trigger point by producing short-term anti-nociceptive effects on the trigger points, according to those authors. 
The results of the current study in increasing the cervical ROM in both groups agree with the results achieved by Draper et al. (2010). The researchers discovered that US increased the range of motion by decreasing the sensitivity of sensory receptors in skeletal muscle, such as the muscle spindle and high threshold mechanoreceptors. Morishita et al. (2011) revealed that applying therapeutic ultrasound to the upper trapezius muscle reduced muscle stiffness and increased active range of motion. US increases skin and muscle extensibility due to the thermal effect on tissue viscoelasticity.

The findings of the current study supported the explanation done by Simons (2002), who indicated that the superimposed effect of the Ischemic Compression (IC) technique reduces radiating headache pain in the study group compared with the control group. Pressure treatments, according to the author, have a variety of therapeutic mechanisms. The length of the sarcomeres in the involved MTrPs can be equalized with local pressure, which leads to a decrease in pain intensity and radiation.

IC can also alleviate fatigue and improve local circulation, according to Mokri et al. (2013) and Mars et al. (2005). Furthermore, it is fair to assume that after using the IC technique, patients with tension headache will improve postural stability. In the follow up period, manual treatment was found to decrease the frequency and the severity of radiating headache pain (Castien, Danielle, Grooten \& Dekker, 2010).

Moraska et al. (2017) conducted a study on 62 patients with chronic tension headache in the same setting. These patients were randomly assigned to receive 12 sessions of US and IC in bilateral upper trapezius and suboccipital muscles MTrPs twice weekly. The authors discovered that IC technique raised the pressure pain threshold at the suboccipital and upper trapezius MTrPs in people with radiating tension headache, and that there were also additional improvements occurred after IC treatments in MTrP tenderness.

Also, in the current study there was an increase in the cervical ROM in patients within the study group, but when comparing the two groups the difference was clinically but not statistically significant. These findings are consistent with those of Aguilera et al (2009). The authors discovered that combining an IC approach with US therapy was an effective method in treating MTrPs in individuals with cervical pain, by reducing pain levels and improving active neck ROM.

Yin-Chou et al. (2011) also discovered that the IC enhances cervical spine ROM and that this is due to muscle relaxation, which is achieved via sensory feedback to the spinal cord and re-adjusting the integrated reflex pathway to re-normalize muscle tonic activity imbalances. 


\section{LIMITATIONS}

The current research is constrained by the inability to extrapolate results from the female population to the male population. Females were tested because the condition is more common in women than in men (Majlesi \& Unalan, 2010). Furthermore, because this study focused just on individuals with Tension Type Headache caused by MTrPs, the findings should not be applied to other patients suffering from headache caused by any other cause.

\section{CONCLUSIONS}

- It can be concluded that ultrasound alone or accompanied with ischemic compression (IC) technique is effective for releasing cervical myofascial trigger points.

- It has subsequent positive effects on the radiating headache and cervical ROM in healthy females after normal delivery.

- The Ischemic Compression approach was an addition to the US in terms of reducing headache pain intensity, but its effect on improving cervical ROM was practically but not statistically significant.

\section{REFERENCES}

1. Agarwal, S., Allison. G. T., \& Singer K. P. (2005). Reliability of the spin-T cervical goniometer in measuring cervical range of motion in an asymptomatic Indian population. Journal of Manipulative and Physiological Therapeutics, 28(7), 487-492.

2. Aguilera, F. J. M., Martín, D. P., Masanet, R. A., Botella, A. C., Soler, L. B., \& Morell, F. B. (2009). Immediate effect of ultrasound and ischemic compression techniques for the treatment of trapezius latent myofascial trigger points in healthy subjects: a randomized controlled study. Journal of manipulative and physiological therapeutics, 32(7), 515-520.

3. Bijur, P., Wendy, S., \& Gallagher, J. (2001). Reliability of the Visual Analog Scale for Measurement of Acute Pain. Journal of the Society for Academic Emergency Medicine, 12(8), 1153-1157.

4. Borg-Stein, J., \& Dugan, S. A. (2007). Musculoskeletal disorders of pregnancy, delivery and postpartum. Physical medicine and rehabilitation clinics of North America, 18(3), 459-476.

5. Carlsson A. (1983) Assessment of chronic pain. I. Aspects of reliability and validity of the Visual Analogue Scale. Pain, 16(1), 87-101.

6. Castien, F., Danielle, A., Grooten, A., \& Dekker, J. (2010) Effectiveness of manual therapy for chronic tension-type headache: A pragmatic, randomized clinical trial. Cephalalgia, 31(2), 133-143.

7. Couppé, C., Torelli, P., Fuglsang-Frederiksen, A., Andersen, K. V., \& Jensen, R. (2007). Myofascial trigger points are very prevalent in patients with chronic tension-type headache: a double-blinded controlled study. The Clinical journal of pain, 23(1), 23-27.

8. De Koning, C. H., Van den Heuvel, S. P., Staal, J. B., Smits-Engelsman, B. C., \& Hendriks, E. J. (2008). Clinimetric evaluation of active range of motion measures in patients with nonspecific neck pain: a systematic review. European Spine Journal, 17(7), 905-921. 
9. Draper, D. O., Mahaffey, C., Kaiser, D., Eggett, D., \& Jarmin, J. (2010). Thermal ultrasound decreases tissue stiffness of trigger points in upper trapezius muscles. Physiotherapy theory and practice, 26(3), 167-172.

10. Dusunceli, Y., Ozturk, F., Atamaz, S. H. \& Durmaz, B. (2009) Efficacy of neck stabilization exercises for neck pain: A randomized controlled study. Journal of Rehabilitation Medicine, 41(8), 626-631.

11. Farooq, M. N., Bandpei, M. A. M., Ali, M., \& Khan, G. A. (2016). Reliability of the universal goniometer for assessing active cervical range of motion in asymptomatic healthy persons. Pakistan journal of medical sciences, 32(2), 457.

12. Fernandez-de-Las-Penas, C., Cuadrado, M. L., Arendt-Nielsen, L., Simons, D. G., \& Pareja, J. A. (2007). Myofascial trigger points and sensitization: an updated pain model for tension-type headache. Cephalalgia, 27(5), 383-393.

13. Fernández-de-Las-Peñas, C., Ge, H. Y., Alonso-Blanco, C., González-Iglesias, J., \& ArendtNielsen, L. (2010). Referred pain areas of active myofascial trigger points in head, neck, and shoulder muscles, in chronic tension type headache. Journal of bodywork and movement therapies, 14(4), 391-396.

14. Ferreira, M., \& Herbert, R. (2008). What does 'clinically important' really mean? The Australian Journal of Physiotherapy, 54(4), 229-230.

15. Gerwin, R. D. (2005). A review of myofascial pain and fibromyalgia-factors that promote their persistence. Acupuncture in medicine, 23(3), 121-134.

16. Goldszmidt, E., Kern, R., Chaput, A., \& Macarthur, A. (2005). The incidence and etiology of postpartum headaches: a prospective cohort study. Canadian Journal of Anesthesia, 52(9), 971977.

17. Hsieh, Y. L. (2005). Reduction in induced pain by ultrasound may be caused by altered expression of spinal neuronal nitric oxide synthase-producing neurons. Archives of physical medicine and rehabilitation, 86(7), 1311-1317.

18. Kavadar, G., Çağlar, N., Özen, S., Tütün, S., \& Demircioğlu, D. (2015). Efficacy of conventional ultrasound therapy on myofascial pain syndrome: a placebo controlled study. Agri, 27(4), 190-196.

19. Kumar, G., Sneha, P., \& Sivajyothi, N. (2015). Effectiveness of Muscle energy technique, Ischemic compression and strain counterstain on Upper Trapezius Trigger Points: A comparative study. International Journal of Physical Education, Sports and Health, 1(3), 2226.

20. Macarthur, A. (2009) Postpartum headache. In: Chestnut, D., Polley, L., Tsen, L., Wong, C., eds. Chestnut's Obstetric Anesthesia Principles and Practice, 4th Ed. Philadelphia: Mosby Elsevier; pp.677-700.

21. Majlesi, J., \& Unalan, H. (2010). Effect of treatment on trigger points. Current pain and headache reports, 14(5), 353-360.

22. Marcus, D., \& Bain, P. (2009). Effective Migraine Treatment in Pregnant and Lactating Women: A Practical Guide. Humana Press, Springer Science, Business Media, LLC; pp.101102.

23. Mars, M., Maharaj, S. S., \& Tufts, M. (2005). The effect of compressed air massage on skin blood flow and temperature: cardiovascular topic. Cardiovascular Journal of South Africa, 16(4), 215-219.

24. Mokri, B. (2013). Spontnaeous low pressure, low CSF Volume Headaches: spontaneous CSF leaks, American Headache Society. Journal of Head and Face Pain,53, 1034-1053.

25. Moraska, A. F., Schmiege, S. J., Mann, J. D., Burtyn, N., \& Krutsch, J. P. (2017). Responsiveness of myofascial trigger points to single and multiple trigger point release 
massages-a randomized, placebo controlled trial. American journal of physical medicine \& rehabilitation, 96(9), 639-645.

26. Morishita, K., Karasuno, H., Fujiwara, T., Fujimoto, T., \& Abe, K. (2011). Effect of the therapeutic ultrasound on muscle hardness and range of motion. J Appl Bio-metrology, 2, 7-10.

27. Rahmani, N., Amiri, M., Ali Mohseni-Bandpei, M., Mohsenifar, H., \& Pourahmadi, M. R. (2013). Work related neck pain in Iranian dentists: An epidemiological study. Journal of back and musculoskeletal rehabilitation, 26(1), 9-15.

28. Robertson, J., \& Baker, G. (2001). A Review of Therapeutic Ultrasound: Effectiveness Studies. Physical Therapy, 81(7), 1339-1350.

29. Dommerholt, J., \& Simons, D. G. (2008). Myofascial Pain Syndrome-Trigger Points. Journal of Musculoskeletal Pain, 16(3), 211-228.

30. Simons, D. G. (2002). Understanding effective treatments of myofascial trigger points. Journal of Bodywork and movement therapies, 6(2), 81-88.

31. Simons, D. (2004). Review of enigmatic MTrPs as a common cause of enigmatic musculoskeletal pain and dysfunction. Journal of Electromyography and Kinesiology, 14. 95107.

32. Srbely, J. Z., Dickey, J. P., Lowerison, M., Edwards, A. M., Nolet, P. S., \& Wong, L. L. (2008). Stimulation of myofascial trigger points with ultrasound induces segmental antinociceptive effects: a randomized controlled study. Pain, 139(2), 260-266.

33. Watson, T. (2000). The role of electrotherapy in contemporary physiotherapy practice. Manual therapy, 5(3), 132-141.

34. Williams, M. A., Williamson, E., Gates, S., \& Cooke, M. W. (2012). Reproducibility of the cervical range of motion (CROM) device for individuals with sub-acute whiplash associated disorders. European spine journal, 21(5), 872-878.

35. Yankai, A., \& Manosan, P. (2009). Reliability of the universal and invented gravity goniometers in measuring active cervical range of motion in normal healthy subjects. The International Journal of Applied Biomedical Engineering, 2(1), 49-53.

36. Lin, Y. C., Lai, C. H., Chang, W. H., Tu, L. W., Lin, J. C., \& Chou, S. W. (2012). Immediate effects of ischemic compression on neck function in patients with cervicogenic cephalic syndrome. Journal of manipulative and physiological therapeutics, 35(4), 301-307.

\section{AUTHOR CONTRIBUTIONS}

All authors listed have made a substantial, direct and intellectual contribution to the work, and approved it for publication.

\section{CONFLICTS OF INTEREST}

The authors declare no conflict of interest.

\section{FUNDING}

This research received no external funding.

\section{COPYRIGHT}

(C) Copyright 2021: Publication Service of the University of Murcia, Murcia, Spain. 